\title{
You can lead a Lady to water, but can you make her drink? Rings of Rhetoric in Jean Renart's Lai de l'Ombre
}

\author{
Linda Marie ROUILLARD
}

7 he art of rhetoric, or the technique of elegant speech and verbal persuasion, finis persuader dictione, is a legacy of classical an-

1 tiquity to the Middle Ages, a legacy which is a foundation for Jean Renart's short lyric poem, Le Lai de l'Ombre. More immediately, Jean follows in the footsteps of Andreas Capellanus's De arte honeste amandi, which models some of the rhetorical devices useful to a courtly lover. ${ }^{1}$ Inspired by Ovid, Andreas presents eight model dialogues demonstrating how a man is to woo women of his social rank as well as women who are more noble or less noble than he. However, it is important to note that the model dialogues end in stalemate rather than in amorous success. The process is one of attempting in debate form to persuade the woman to become une amie. In this competition, the contestants are rhetorical equals, the woman serving as the voice of reason, balancing the man's shrewd rhetorical manipulations. The closest he comes to success is to get the woman to agree to consider a relationship and the encounters never progress beyond the verbal realm.

On the other hand Jean Renart's Lai de l'Ombre, dated from 1200 to $1222,{ }^{2}$ tells a traditional courtly love story which, in contrast to Andreas' rhetorical exercises, does end successfully, but only when rhetoric is supplemented by gesture. ${ }^{3}$ My interest here is to consider how the Lai de 
l'Ombre proceeds past the failure of rhetoric such as we see in Andreas' text and arrives at a positive amorous outcome by means of gesture.

By dividing his first book into model dialogues, Andreas has implicitly labeled his work as one about rhetoric. The sample discourse shows what language to use and how language is used in an act of persuasion. Similarly, in Jean Renart's Lai, the amorous seduction can certainly be read as an apt metaphor for the linguistic act of persuasion in general and as an analogy for the assignation of meaning in particular. Such a reading which privileges linguistic preoccupations seems entirely justified, given Jean's later work Le Roman de la Rose ou de Guillaume de Dole with its insertions of forty-six lyric pieces within the romance itself. Norris Lacy has pointed out that this romance is one which "[offers] us a drama of language, of song and tale, rather than of action and intrigue."4 Much the same is true of this shorter work, as the narrator states in the first three lines:

Ne me vueil pas desaüser de bien dire, ainçois vueil user mon sens a el qu'a estre oiseus. ${ }^{5}$ (11 1-3)

With his desire "de bien dire," the narrator/poet thus announces his interest in rhetoric, and his affinity with classical authors. Cicero defined rhetoric as follows: "The function of eloquence seems to be to speak in a manner suited to persuade an audience, the end is to persuade by speech." Likewise, Quintilian defined rhetoric as, "the science of speaking well." Jean's comparisons between the knight and Tristan (11 105,124 and 457) also emphasize this interest in rhetoric, for Tristan was a supreme manipulator of words and signs. ${ }^{8}$

Of Andreas's treatise, Toril Moi says it is "remarkable how little sexual success the lovers in these dialogues have in proportion to their verbal efforts: the prowess is linguistic not erotic." ${ }^{\prime 2}$ Likewise in Jean Renart's $L a i$, the knight's valor resides in his rhetorical abilities.

In the $L a i$, love is born in the traditional fashion: the female deity attacks with bow and arrow and implants the image of a beautiful woman along with her name in the knight's heart which triggers the first symptom of love: obsession. "La grant biauté et le douz non /d'une dame li mist el cuer." (11. 130-131) As the knight is subjected to this power of a word and an image, he will in turn attempt to subjugate others to the power of his rhetoric. ${ }^{10}$ In his first rhetorical manœuvre he manipulates his traveling companions. By saying one thing while meaning another, he gets them to 
pronounce his own feelings, manipulating them into taking the words out of his mouth. Observing a very important precept of Love, that is the need for secrecy, the knight feigns an overwhelming admiration for the castle where the Lady lives, leaving his companions to praise the beauty of the woman herself:

Fet li sires quis i menoit:

'Veez con cil chastiaus siet bien!'

Il nel disoit pas tant por rien

qu'il montast aus fossez n'aus murs, mes pour savoir se ses eürs

l'avroit encor si amonté qu'il parlaissent de la biauté la dame qu'il aloit veoir. (11. 226-233)

The other knights rebuke him for praising the castle instead of the Lady's beauty. He admires the edifice once again, saying he would happily be a prisoner of Saladin if this castle were his: "Il n'est citez dont j'ai envie/ ne chastiaus, se de cesti non," (11. 248-49), to which his companions reply:

'Et quanqu'il a dedenz les murs?

font cil. Si en seriez trop sire!'

Il n'entendent pas a cel dire

le sofisme qu'il lor fesoit:

li bons chevaliers nel disoit

se por oïr non qu'il diroient. (11. 254-259)

The sofisme is created by the manipulation of the meaning of "chastiaus." The companion knights have at first not understood the metonymy of the castle used to signify the Lady, the "container". substituted for that which is "contained." Jean Renart's use of the word sofisme in this passage underlines the importance of rhetoric itself to the Lai and the potential danger. In addition to persuading, rhetoric can deceive. " Indeed, in this passage of the Lai, the knight manipulates his companions towards the pronouncement he himself must not utter in order to observe the secrecy needed to protect his own interests. This rhetorical substitution of "chastiaus" for the Lady, prefigues the pivotal metonymy in which the reflection at the bottom of the well is substituted for the Lady herself, whose image is still of one "contained," this time within the structural framework of the fountain. In addition, the metonymic chastiaus sofisme 
also functions as an implicit metaphor which equates woman with land to be seized and held. ${ }^{12}$

While the companions may be unaware of the knight's linguistic manœuvres, the Lady shows more resilience to his first level of love rhetoric. In response to his confession that he is completely in her power and to his plea that she become his amie, she answers with a challenge: if he is as worthy a knight as indeed he appears to be, he must surely already have an amie (11.377-387). That this encounter is a rhetorical joust is in fact emphasized by the narrator who says: "Bien l'a en son venir hurté/ par parole et desfet son conte ..."(11.388-389). In his edition, Bédier's gloss of this line points out that "hurté" belongs to the knight's vocabulary used to describe the action of striking a blow and blocking the opponent. ${ }^{13}$ She further challenges his rhetorical sallies with arguments about nobility of character which requires nobility of action:

Sire, fet ele, n'est pas droiz, par Dieu, que j'aim ne vous ne honme, que j'ai mon seignor, et preudonme, qui mout me sert bien et honeure. (11. 492-495)

The Lady is thus portrayed as a worthwhile adversary and well-trained in rhetoric, able to unravel the knight's argument by calling into question his own moral character as a worthy ami. Her demonstrated rhetorical skills make her a much more satisfying opponent and the knight's ultimate victory that much more gratifying.

Since traditional rhetoric has failed the knight, he must move to a stronger level of persuasion: the use of a kind of force, though certainly not the same kind of physical force described by Andreas as allowed only when dealing with the lower classes. ${ }^{14}$ The knight takes advantage of the Lady's distraction and succeeds in placing his ring on her finger, thus establishing a kind of proprietorship, imposing his will upon her. ${ }^{15}$ This reading is entirely justified by the Lady's own interpretation of the act: "Volez le me vous fere avoir/a force?" (11. 802-803) aptly noted by Sarah Kay and labeled as a "second sofisme, physical rather than verbal." 16 The knight's attempted "courtly" manner and apparently generous gifts recall the following passage in Book Two of Ovid's Amores with its sexual connotations of the ring:

O ring, that art to circle the finger of my fair lady, in which naught is of value but the giver's love, mayst 
thou go to her a welcome gift! May she receive thee with glad heart and straightway slip thee on her finger; mayst thou fit her as well as she fits me, and press her finger with aptly adjusted circle!

Happy ring, thou wilt be touched by the hands of my lady-love; already, ah, me, I envy my own gift. Ah, might I suddenly become that gift ... Wear me when you spray yourself with the warm rain of the bath, nor shrink at the harm from water creeping beneath the gem-but methinks my passions would rise at sight of your fairness, and $\mathrm{I}$, though naught but that ring, would play the human part. ${ }^{17}$

While Ovid describes his ring as worthless, Jean Renart's knight sees his ring appreciate in value simply by being in contact with the Lady: "de tant vaut il miex la moitié / qu'il a en vostre doit esté" (11. 738-739). While Jean's use of the ring is less sexually explicit than Ovid's, sexual and misogynist overtones remain attached to the ring motif as it is used in this ironic episode of a "gift by force."18

Only after the knight's sudden departure, does the lady notice the ring: "de l'anel qu'il m'a el doit mis/or dira qu'il est mes amis" (11. 625-626)! She knows she has been taken advantage of and has been "branded" as another man's conquest. She is also aware of the potential blackmail of this situation. The ring on her finger will be taken to mean she is the knight's amie, ${ }^{19}$ that it symbolizes her acceptance of the knight as her lover, her acceptance of his meaning of the ring as symbol. ${ }^{20}$ The presence of the knight's ring upon her finger is thus as susceptible to misinterpretation, as were her initial welcoming gestures: ${ }^{21}$

Je n'entendoie au regart rien se cortoisie non et sens.

Mes vous l'avez en autre assens noté conme fols, si m'en poise ...(11. 424-427) $)^{22}$

The Lady answers this act of force or this forced meaning with a plan of action which will clearly demonstrate her refusal of that meaning: she will summon the knight, lead him to the edge of a well, and if he refuses to take his ring back, she will simply drop it into the water where it will disappear from sight. 
Sitting by the well, once again the knight attempts to convince the Lady. When he has reached yet another verbal impasse, he stumbles upon the solution: he will accept the return of the ring only with the understanding that he will be once again a free agent, at liberty to do whatever he wishes with the ring. He then announces he will offer it to the one he loves most after her. In a manner reminiscent of Ovid's assessment that "Quod refugit, multae cupiunt," ${ }^{23}$ the knight drops the ring towards the Lady's reflection (which is one meaning of ombre) in the well. The Lady earlier argued that her nobility of character required nobility of action, which is based on a kind of moral pride. This pride opens up a narcissistic breach in the Lady's resistance and the knight's seductive gesture triggers jealousy and a reciprocal offer: the Lady now offers the knight her own ring and becomes his amie. Sarah Kay contrasts the classical Narcissus myth in which the "reflection mimics the actions of the young man," with the Lady who now "imitates the conduct of her image." 24 Or, to paraphrase another critic, it is the knight's "infidelity" which effects the Lady's "fidelity." 25

In this final scene of the Lai, the ring is tossed towards the reflection as a baited hook, in much the same way that Andreas defines love by referring to Isidore of Seville's false "etymology" for the word "amicus" which he derives from the word "hamus." Andreas writes:

Amor is derived from the verb amo, meaning catch or be caught, for the lover is caught in bonds of desire and longs to catch another on his hook (hamo). Just as a clever angler tries to entice the fish with his morsels and to catch them on his bent hook, so the man ensnared by love tries to attract another by his charms. He strives with every effort to join two separated hearts with an imperceptible bond, or to keep them once joined always together ... ${ }^{26}$

Toril Moi comments on this passage: "The De Amore does, of course, also present language as the 'hook of love' which allows the lover to attract the lady by his 'allurements' in order to create an 'intangible bond' between their hearts." ${ }^{27}$ In the Lai, tossing the ring towards a supposedly new love interest is the bait with which the knight hooks his Lady, whom the narrator earlier described: "mes n'est encor preu en la nasse." (1. 726) This attempt at persuasion now includes an alluring and even inventive gesture. ${ }^{28}$ As Don Alfred Monson has noted, Jean Renart has himself 
highlighted the efficacy of word and gesture: "cist douz mot et li plesant fez" (1.933) ${ }^{29}$ Rather than using overt physical force, the knight can rely on a seductive gesture along with his rhetorical talents to figuratively lead the Lady to the edge of the well and persuade her to drink, in a sense reducing her to her own reflection. ${ }^{30}$ As Alfred Adler expressed it: "Pour ce couple d'amants, la non-réalité de l'ombre dans le puits, se révèle la réalité la plus réelle." 31

While Ovid's ring motif and Andreas's model dialogues may present an inadequate rhetoric of love, this final scene of Jean Renart's Lai presents the love (if not the success) of rhetoric, amplified by gesture, and gesture which becomes poetry. A courtly love scene is a useful context in which to better understand the development and manipulation of the rhetorical process of persuasion. In contrast to the pastourelle genre which aims at "the demystification of fin'amor," 32 the Lai de l'ombre clearly insists on maintaining the illusions of the courtly tradition.

Wabash College 


\section{Notes}

1. Barbara Nelson Sargent[-Baur], "The Lai de L'Ombre and the De Amore," Romance Notes 7 (1965), 76-79, following the lead of Patricia Terry, ed. and trans., Le Lai de l'Ombre, (Columbia Univ. diss., 1958). And Felix Lecoy in his introduction to Le Lai de l'Ombre (Paris: Librairie Honoré Champion, 1979), xvii-xviii. Paula Clifford also cites J. Stevens as another proponent of this view in her book La Chastelaine de Vergi and Jean Renart: Le Lai de l'Ombre (London: Grant \& Cutler Ltd., 1986), 57. Don Alfred Monson, "Lyrisme et narrativité dans le Lai de l'Ombre," Cahiers de Civilisation Médiévale, XXXVI (1993), 60-69, rejects this influence, classifying this text rather as the juncture between "fond lyrique et forme narrative."

2. Lecoy, xiii-xv. Lecoy traces the different chronologies suggested for the Lai: 1221-1222 if one concludes the dedicatee is Milon de Nanteuil, or 1200-1202 if one concludes the dedicatee to be Hugues de Pierpont. See also John Baldwin, “"Once there was an emperor ...' a Political Reading of the Romances of Jean Renart," Jean Renart and the Art of Romance: Essays on Guillaume de Dole, ed. Nancy Vine Durling (Gainesville: University Press of Florida, 1997), 51, who also proposes Hugues de Pierpont.

3. Clifford, 69-80. Regarding the knight's success at slipping the ring on the Lady's finger, unbeknowst to her, Clifford says: "Already we witness the failure of language, for a gesture is needed ..." (71). She ultimately sees in the Lai a "breakdown of language and its replacement by gesture" (75). See also Margaret Winters, Jean Renart: Le Lai de l'Ombre (Birmingham: Summa Publications, 1986), 10.

4. Norris Lacy, "AAmer par oïr dire': Guillaume de Dole and Language," French Review 54(1981), 786.

5. Unless stated otherwise, all citations of the Lai are taken from Lecoy's edition.

6. Cicerco, De inventione, ed. H. M. Hubbell (Cambridge: Harvard University Press, 1949), 15.

7. Quintilian, Institutio Oratoria, trans. H. E. Butler (Cambridge: Loeb, 1980), Book II, XV, 319.

8. Linda Cooper, "The Literary Reflectiveness of Jean Renart's Lai del'Ombre," Romance Philology35 (1981), 255-257. Jean's interest in the Tristan legend is even more evident in his Escoufle. See Rita Lejeune, "La Coupe de la légende de Tristan dans L'Escoufle de Jean Renart," in The Medieval Alexander Legend and Roman Epic, ed. Peter Noble, et al. (New York: Kraus International, 1982), 118-124. 
9. Toril Moi, "Desire in Language: Andreas Capellanus and the Controversy of Courtly Love," Medieval Literature: Criticism, Ideology, and History, David Aers, ed. (New York: St. Martin's Press, 1986), 24.

10. Moi, 24, comments on an analogous passage in the De amore: "Chained and fettered, the lover's discourse enacts his own lack of freedom, which is bearable only because it procures him at the same time the satisfaction of a certain sadistic dominance." The relationship between the knight and the Lady in the Lai is in some respects similar, but the overall effect of their encounter is a charming one, not a sadistic one.

11. Quintilian summarizes some of the accusations made against the value of rhetoric: "It is eloquence" they say, "that snatches criminals from the penalties of the law, eloquence that from time to time secures the condemnation of the innocent..." (319).

12. Leo C. Curran, "Rape and Rape Victims in the Metamorphoses" Arethusa 11 (1978), 232. And Ian Donaldson, The Rapes of Lucretia: A Myth and its Transformations (Oxford: Clarendon, 1982), 10.

13. Le Lai de l'ombre par Jean Renart, ed. Joseph Bédier (Paris: Firmin- Didot, 1913), 80. Lecoy, xvii-xviii. Glyn S. Burgess, "Sens and Cortoisie in the Lai de l'Ombre," Michigan Romance Studies (1989), 79.

14. Andreas, as translated in P. G. Walsh, Andreas Capellanus on Love (London: Gerald Duckworth \& Co., 1982), 223: "But if the love even of peasant women chances to entice you, remember to praise them lavishly, and should you find a suitable spot you should not delay in taking what you seek, gaining it by rough embraces."

15. Jean Larmat, "La morale de Jean Renart dans Le Lai de l'Ombre," Mélanges de Philologie offerts à Charles Camproux, 1 (Montpellier: CEO, 1978), 411, says of the ring: "c'est quelque chose de lui qu'il offre, mais avec quoi il lie pour ainsi dire la jeune femme, comme s'il prenait possession d'elle par une saisine symbolique." Cooper has commented on the intertextuality of the ring motif in Jean's own work, 252.

16. Sarah Kay, "Two Readings of the Lai de l'Ombre," Modern Language Review 75 (1980), 520-522. Clifford, 67.

17. Ovid, Heroides and Amores, trans. Grant Showerman (New York: G. P. Putnam's Sons: 1925), 427-29.

18. Larmat, 414.

19. Kay, 520.

20. Roger Pensom, "The Lai de l'Ombre," French Studies 36 (1982), explains the episode of the furtive placement of the ring on the Lady's finger as her dissociation from her secret desire, 263.

21. Burgess, "Sens," 84-85 for a discussion on intention vs. interpretation and meaning. 
22. Kay, 520: "[the knight] misinterprets the graciousness of the lady's welcome, reading into it a courteous recognition of his suit ... he has mistaken the conventions of politeness for an indication of true feeling."

23. "Many women desire what flees them," Ovid, The Art of Love and Other Poems, trans. J. H. Mozley, 2nd ed. rev. G. P. Goold (Harvard: Loeb, 1985), 60-61.

\section{Kay, 526.}

25. Monson, 68. Glyn S. Burgess reads this episode as one which "undermine[s] courtly conventions." See his "Role of the Heart in the Lai de l'Ombre and the Chastelaine de Vergi," Faux Titre, ed. Keith Busby (Atlanta: Rodopi, 1994), 40.

26. Andreas in Walsh, 36-37. In this, Andreas is also imitating Ovid who often uses hunting and fishing metaphors for love. See Ovid, ed. Goold, 14, lines 45-48 and 64 line 763 of Book 1 .

27. Moi, 25.

28. Quintilian explained the value of accompanying gestures to the force of rhetoric by recounting a courtroom scene: Antonius defended Manius Aquilius' character, not by words alone, but also by ripping the latter's clothing to show his battle scars, 303 .

29. Monson, 68. In addition, he sees in the Lai's resolution a precursor to the Petrarchist "pointe," the concluding verses to the Renaissance sonnet. Of the lai's resolution, Glyn S. Burgess says: "It was the knight's sens, his intellectual manipulation of action and gesture, which was the significant element," in "The Role of the Heart," (39).

30. Douglas Kelly makes an interesting connection between heroines of Chrétien de Troyes and Jean Renart: "The transposition of the description of Blancheflor into the blood drops image is analogous to that of the lady into her 'shadow' or reflection in the fountain in the Lai de l'Ombre," 219, "The Art of Description," in The Legacy of Chrétien de Troyes, ed. Norris Lacy, et al. (Amsterdam: Rodopi, 1987).

31. Alfred Adler, "Rapprochement et Eloignement comme thèmes du Lai de l'Ombre," Etudes de Philologie Romane et d'Histoire Littéraire offertes à Jules Horrent, ed. Jean Marie d'Heur, et al. (Liège: Gedit, 1980), 2.

32. William Calin, "Contre la Fin'amor," in Courtly Literature: Culture and Context, ed. Keith Busby and Erik Kooper (Philadelphia: John Benjamins Publishing Co., 1990), 72. Translation is mine. 


\section{Works Cited}

Adler, Alfred. "Rapprochement et Eloignement comme thèmes du Lai de l'Ombre." Etudes de Philologie Romane et d'Histoire Littéraire offertes à Jules Horrent. Ed. Jean Marie d'Heur et Nicoletta Cherubini. Liège: Gedit, 1980. 1-4.

Baldwin, John. "'Once there was an emperor ... a a Political Reading of the Romances of Jean Renart." Jean Renart and the Art of Romance: Essays on Guillaume de Dole. Ed. Nancy Vine Durling. Gainesville: University Press of Florida, 1997.45-84.

Bédier, Joseph, ed. Le Lai de l'Ombre. By Jean Renart. Paris: FirminDidot, 1913.

Burgess,Glyn S. "Sens and Cortoisie in the Lai de l'Ombre." Michigan Romance Studies (1989): 71-91.

. "Role of the Heart in the Lai de l'Ombre and the Chastelaine de Vergi." Faux Titre. Ed. Keith Busby. Atlanta: Rodopi, 1994.31-47.

Calin, William. "Contre la Fin 'amor." Courtly Literature: Culture and Context. Ed. Keith Busby and Erik Kooper. Philadelphia: John Benjamins Publishing Co., 1990.61-82.

Cicerco. De inventione. Ed. H.M. Hubbell. Cambridge: Harvard University Press, 1949.

Clifford, Paula. La Chastelaine de Vergi and Jean Renart: Le Lai de l'Ombre. London: Grant \& Cutler Ltd., 1986.

Cooper, Linda. "The Literary Reflectiveness of Jean Renart's Lai de

l'Ombre." Romance Philology 35 (1981): 250-60.

Curran, Leo C. "Rape and Rape Victims in the Metamorphoses." Arethusa $11(1978): 213-41$.

Donaldson, lan. The Rapes of Lucretia: A Myth and its Transformations. Oxford: Clarendon, 1982.

Kay, Sarah. "Two Readings of the Lai de l'Ombre." Modern Language Review 75(1980):515-27.

Kelly, Douglas. "The Art of Description." The Legacy of Chrétien de Troyes. Ed. Norris Lacy, et al. Amsterdam: Rodopi, 1987.

Lacy, Norris. "Amer par oïr dire': Guillaume de Dole and Language." French Review 54 (1981): 779-87.

Larmat, Jean. "La morale de Jean Renart dans Le Lai de l'Ombre." Mélanges de Philologie offerts à Charles Camproux. Montpellier: CEO, 1978.407-16.

Lecoy, Felix, ed. Le Lai de l'Ombre. By Jean Renart. Paris: Librairie Honoré Champion, 1979. 
Lejeune, Rita. "La Coupe de la légende de Tristan dans $L$ 'Escoufle de Jean Renart." The Medieval Alexander Legend and Roman Epic. Ed. Peter Noble, et al. New York: Kraus International, 1982. 119-124.

Moi, Toril. "Desire in Language: Andreas Capellanus and the Controversy of Courtly Love." Medieval Literature: Criticism, Ideology, and History. Ed. David Aers. New York: St. Martin's Press, 1986. 11-33.

Monson, Don Alfred. "Lyrisme et narrativité dans le Lai de l'Ombre." Cahiers de Civilisation Médiévale 36 (1930): 59-71.

Ovid. Heroides and Amores. Trans. Grant Showerman. New York: G. P. Putnam's Sons, 1925.

. The Art of Love and Other Poenis. Trans. J. H. Mozley. 2nd ed. G.

P. Goold. Harvard: Loeb, 1985.

Pensom, Roger. "The Lai de l'Ombre." French Studies 36 (1982) : 257-69. Quintilian. Institutio Oratoria. Trans. H. E. Butler. Cambridge: Loeb, 1980. Sargent[-Baur], Barbara Nelson. "The Lai de L'Ombre and the De Amore." Romance Notes 7 (1965) : 73-79.

Walsh, P.G., trans. Andreas Capellanus on Love. London: Gerald Duckworth \& Co., 1982.

Winters, Margaret. Jean Renart: Le Lai de l'Ombre. Birmingham: Summa Publications, 1986. 